\title{
Experience with Online Delivery of an Engineering Technical Elective Course
}

\author{
Jim Wallace and Harpreet Dhariwal \\ Faculty of Applied Science and Engineering, University of Toronto \\ wallace@mie.utoronto.ca
}

\begin{abstract}
MIE 515, Alternative Energy Systems, an engineering technical elective course open to senior undergraduates and graduate students, was delivered as an on line course for Fall 2011. This is the first time an undergraduate engineering course at the University of Toronto has been offered online. The course is also one of five pilot online courses across the University. The move online is being accomplished in two steps. For Fall 2011, a small lecture section of 25 students was used as a setting for video capture and the remaining 110 students accessed the course lectures online asynchronously. A live tutorial was offered once a week. All students were physically present for the midterm examination and the final examination. For Fall 2012, the course will be delivered entirely online, with the exception of student physical presence for the two examinations.

Pedagogical and technical lessons learned during this transition year will be presented. The benefits and drawbacks of online delivery will be discussed from the perspective gained this year and compared with our expectations. Student feedback will also be presented and discussed.
\end{abstract}

Keywords: Online course, vi deo capture, engineering technical elective, alternative energy systems

\section{INTRODUCTION}

MIE 515, Al ternative Energy Systems, is an engineering technical elective course that has been taught annually since the winter term of 2002. The list of topics covered has evolved significantly over the years and now includes solar energy, wind energy, wave and tidal energy, energy storage, and grid connection issues. The field is continually evolving, so the course material must be refreshed each year to stay current. The course serves three distinct groups of st udents, each with different backgrounds and needs. Fourth year undergraduates are the largest group, about $100 \mathrm{in} \mathrm{2011.} \mathrm{St} \mathrm{udents} \mathrm{in} \mathrm{the}$ professional MEng Program, twenty in 2011, constitute the next largest group. For this group, MIE 515 is a core subject to obtain a Certificate in Energy Studies. Finally, there are MASc and PhD students, 15 in 2011, who want to take the course in support of their research. As a result of their sheer numbers, undergraduate dominate the course, to the detriment of $t$ he other two groups. Addressing the needs of al 1 three groups $t$ hrough customization was a strong motivation to explore the use of online technology.

The move online is being accom plished in two steps. For Fall 2011, a sm all lecture section of 25 st udents (all graduate students) was used as a setting for video capture. The remaining $110 \mathrm{st}$ udents, including all of the undergraduates and the remaining graduate students, accessed the course lectures online asynchronously. A live tutorial was offered once a week. All students were physically present for the midterm examination and the final examination. For Fall 2012, the course will be delivered entirely on line, with the exception of student physical presence for the two examinations. This paper describes the technology used and the experience gained delivering the course in Fall 2011.

\section{OVERALL STRUCTURE AND COURSE DESIGN}

Until Fall 2011, the course was taught in the traditional lecture format. There were two 1.5 hour lectures each week and a one hour tutorial, all scheduled in the early evening to $f$ acilitate access for part-tim e students in the professional MEng Program. For 2011, the same lecture arrangement, i.e. two 1.5 hour lectures per week, was $\mathrm{m}$ aintained for the small lecture section used for video capture.

In preparation for the online delivery of MIE 515, the book "Building Online Learni ng Communities, Effective Strategies for the Virtual Classroom," was instrumental in recognizing the essential goal of achieving a community online of all students [1]. However, $t$ he context of the book is entirely hum anities and social sciences, disciplines in which only words are exchanged. The challenge was to facilitate discussion and exchange in an engineering course where sy mbols, formulas, and sample 
calculations are i nvolved. The essent ial first step in creating the online community was to provide regular online activities that required student participation. For the first year trial, a $\mathrm{m}$ ix of traditional problems sets (submitted, marked and returned online) and discussion boards were used. Each of these will be discussed in turn.

\section{ADVANCE ACTIVITIES}

A welcome video that introduced the online course and explained how it would be conducted was recorded and posted to the University of Toront o Portal course management system (Blackboard) in August. As well, a much expanded course sy llabus was al so posted simultaneously to provide details on course organi zation and marking scheme. About 5\% of t he students had questions, but on the whole the video and syllabus were effective in introducing the new course format.

\section{LECTURES}

Lectures are the primary source of information in the course as there isn't a suitable textbook. A supplemental reader [2] is recommended to students, but as a source of additional context rather than technical content. The lectures were organized into modules on speci fic topics (Table 1). Each module covered fundamentals, the technology used, environmental and economic issues, and a case study. For som e topics only a single lecture was required but other modules had as m any as four lectures. The Echo 360 Vi deo Capture system was used to record the lectures. The recorded videos received minor editing and then were posted to the course Blackboard, generally within 24 hours of being recorded. Students could choose between three formats: a streaming video (Rich media), a Vodcast download, or audio only. Whereas much of the previous version of the course was del ivered at the chalkboard, a docum ent camera was utilized for the online lectures to provide a h igher quality image than could be obtained from video capture of the chalk board. A second advantage is that the notes written out on the document camera provided a written record of the lecture as delivered. After each 1 ecture, the docum ent camera notes were scanned and posted on Blackboard along with the video.

Students took considerable time to view the lectures. The number of times the video was accessed for a representative lecture (November $15^{\text {th }}$ ) is shown in Fig. 1. It took until November 30th to reach the num ber of hits equivalent to the number of st udents in the class, but many of the hits shown are multiple hits by the same person. Particularly noteworthy is the spike in viewing in mid-December just prior to the final exam on December $21^{\text {st }}$. It is clear that we have a long way to go to achieve regular engagement by the students.

Table 1. Module and Lecture Organization

\begin{tabular}{|c|c|c|}
\hline Module & Lec & Lecture topic \\
\hline Introduction & 1 & Energy Overview \\
\hline \multirow[t]{3}{*}{$\begin{array}{l}\text { Radiation Heat } \\
\text { Transfer }\end{array}$} & 2 & $\begin{array}{l}\text { Directional and spectral } \\
\text { characteristics }\end{array}$ \\
\hline & 3 & Blackbody radiation \\
\hline & 4 & Surface properties \\
\hline \multirow[t]{3}{*}{ Solar Radiation } & 5 & Atmospheric losses \\
\hline & 6 & Sun-earth relations \\
\hline & 7 & $\begin{array}{l}\text { Estimation of terrestrial } \\
\text { solar radiation }\end{array}$ \\
\hline \multirow[t]{2}{*}{ Solar Collectors } & 8 & $\begin{array}{l}\text { Simple models of solar } \\
\text { collectors }\end{array}$ \\
\hline & 9 & Solar heating systems \\
\hline \multirow[t]{2}{*}{ Passive Solar } & 10 & Passive solar concepts \\
\hline & & Planning for passive solar \\
\hline $\begin{array}{l}\text { Solar Thermal Power } \\
\text { Generation }\end{array}$ & 11 & $\begin{array}{l}\text { Technology and case } \\
\text { studies }\end{array}$ \\
\hline \multirow[t]{3}{*}{ Solar Photovoltaic } & 12 & Photovoltaic fundamentals \\
\hline & 13 & $\begin{array}{l}\text { Equivalent circuits and } \\
\text { characteristics }\end{array}$ \\
\hline & 14 & Case studies \\
\hline \multirow[t]{4}{*}{ Wind Energy } & 15 & Technology fundamentals \\
\hline & 16 & $\begin{array}{l}\text { Wind sources and } \\
\text { influences }\end{array}$ \\
\hline & 17 & $\begin{array}{l}\text { Predicting wind turbine } \\
\text { output }\end{array}$ \\
\hline & 18 & Case studies \\
\hline \multirow[t]{2}{*}{ Wave Energy } & 19 & $\begin{array}{l}\text { Wave energy } \\
\text { fundamentals }\end{array}$ \\
\hline & 20 & $\begin{array}{l}\text { Wave energy converters - } \\
\text { case studies }\end{array}$ \\
\hline Tidal Energy & 21 & Fundamentals and devices \\
\hline \multirow[t]{3}{*}{ Energy Storage } & 22 & Energy storage technology \\
\hline & 23 & $\begin{array}{l}\text { Energy storage applied to } \\
\text { transit systems }\end{array}$ \\
\hline & & Hydrogen energy storage \\
\hline $\begin{array}{l}\text { Grid Connection } \\
\text { Issues }\end{array}$ & 24 & \\
\hline $\begin{array}{l}\text { Future of Renewable } \\
\text { Energy }\end{array}$ & 25 & $\begin{array}{l}\text { Summary and future } \\
\text { prospects }\end{array}$ \\
\hline
\end{tabular}




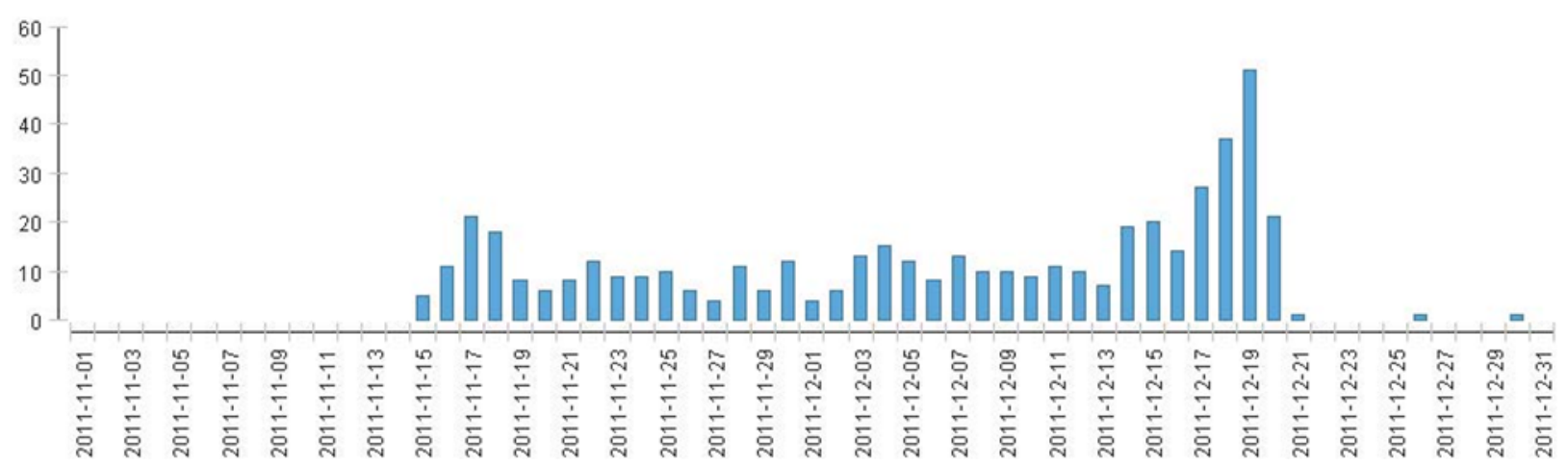

Figure 1. Online viewing of November $15^{\text {th }}$ lecture video - hits per day.

\section{TUTORIAL}

In past years, the course instructor solved som e example problems on the board and then opened the floor for general questions. In a sense, $t$ he tutorial served the purpose of office hours but with questions and answers heard by all present. The example problems and their solutions were posted on Blackboard, so the tutorial was optional. The current generation of students was rai sed with the Internet so it wo uld be logical to assume that they would be enthusiastic about an online course. There was, however, some pushback when the move online was announced. The following excerpt is representative:

"I feel that on-line lectures (at least the way I picture them) take quite a bit away from the learning experience and it's unfortunate that students who picked this course ... have to live with this option. I, for one, would dread to drop this course (particularly since I need it for my environmental minor), but I am quite uneasy with on-line lectures."

Thus, for 2011 a 1 ive tutorial was retained, so that the online cohort had som e opportunity for face-to-face interaction with the instructor. The attendance was quite high at the beginning of the term, but steadily declined as the students learned to make use of online alternatives. Thus, for the transition year, th e live tutorial was successful in reassuring students that their questions would be answered.

With respect to online interaction, a "General Questions" discussion board was in itiated at the beginning of the course, wi th the intent of creating an online forum to respond to broader i ssues, such as technical glitches or administrative questions. In addition, the original plan was to create a separate forum for each lecture so that st udents could pose questions specific to that material. This was duly implemented for the first and second lectures, but quickly abandoned after they received only 1 and 2 posts respectively. In practice, the students posted all of their questions on the "General
Questions" discussion board, no m atter what the topic. Despite being told to post questions to the discussion board rather than send individual e-mail to the instructor, many students still sent e-mail. When this occurred, the instructor posted credible questions received by e-mail on the General Questions discussion board al ong with a response, without identifying the student. On the whole, participation in the General Questions discussion board was very low, only 44 students with 144 posts over the entire term. The low participation may have been due to the live tutorial but a clearer explanation of how questions are to be posted (and answered) will be necessary for fall 2012 when the course is entirely online. It should be noted that of the questions that were posted directly to the discussion board, $m$ ost were answered [correctly] by other students. This suggests that there was a nucleus of the desired online community, although it never grew beyond a small group of students. So, there is both hope for but also a challenge to creating an online com munity in Fall 2012.

With the online course, there is a need to be able to respond online to student questions thoroughly and

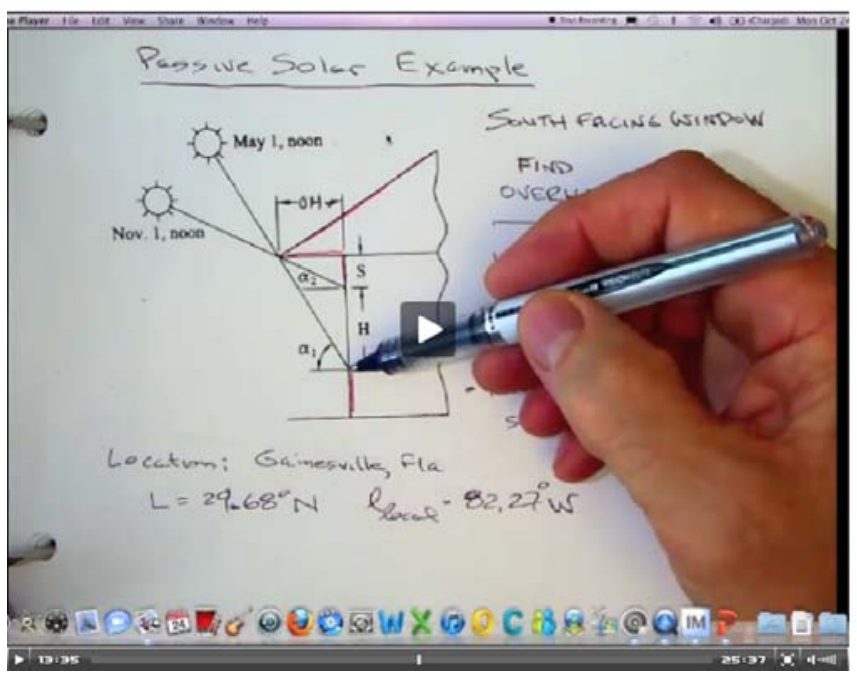

Figure 2. Mini-tutorial example. 
promptly. The use of formulas and sketches necessitates a response with images as well as text. Using features of Echo360 capture software or Apple Quick Time, it was easy to create a mini-tutorial explaining the theory or concept in detail. For example, a formula or a diagram can be written out on paper (a passive solar problem example is shown in Fig. 2) using a document camera to capture the process, while at the same time recording a verbal explanation of the solution as a voi ce-over. The result is then posted to the discussion board.

The advantage of $\mathrm{t}$ his technology is that the instructor can, without the assistance of a $t$ echnician, create an audio-visual response to questions. Our hope is that in the next iteration of the course a comparable (and inexpensive) technology can be devel oped that would enable the students to com municate in a similar fashion. This would really move development of an onl ine learning community forward.

We are also exploring the possibility of implementing a live online session at a scheduled weekly time in place of the previous tutorial. Once again, the document camera would be the enabling technology for an audio-visual response, even if the student questions are written rather audio visual themselves.

\section{TERM WORK}

Students had t o submit some type of assignment weekly as a way of keep ing them up-to-date on the lectures and to provide practice with the $m$ aterial. The assignments were $\mathrm{i} n$ two forms: discussion board participation and problem sets.

\subsection{Discussion Boards}

Since this was the first time discussion boards had been used, st udents were gi ven the opportunity to participate in 3 discussion boards, but only the best two marks were used and these together accounted for $4 \%$ of the final course mark. Discussion board participation was marked using a rubric (developed by others in the Faculty of Applied Science and Engi neering) that allocated 2 marks each to Contribution to Knowledge Base, Relevance, Collaboration, Clarity of Communication and Quality of Feedback. Th e rubric was $p$ rovided to students in advance of their participation in the first discussion board.

There are two places in the course where discussion boards fit well: at the beginning of the course when only introductory material had been del ivered and st udents were not yet able to solve problems, and at the end of the course where a number of topics, e.g. energy storage and grid connection issues, don't lend themselves readily to problem sets. To get student s started, each student was asked to introduce themselves on a discussion board and state what they hoped $\mathrm{t}$ o get from the course. Participation was quite good as 132 of 140 st udents initially enrolled responded.

The Ontario Provincial Election provided a great context for the first marked discussion board, which was posted immediately after the introductory lecture. Students were provided with links to the election platforms of the three main political parties contesting the election and asked $t$ o discuss how the party platforms addressed some of the issues ra ised in the first lecture. Participation was $1 \mathrm{ow}$, only 83 of 136 students (61\%) responded. Those $t$ hat responded did well (average 8.4 out of 10) but quite a few students didn't understand what they were supposed to do and simply didn't participate. Even among those who responded t here was rel atively little discussion - people posted individual comments independently, often starting new threads on the same topic. The lesson was that students need a relatively detailed set o $\mathrm{f}$ instructions for participating in a discussion board.

For the next two marked discussion boards, both near the end of $t$ he course, $m$ ore specific instructions were provided and the responses were si gnificantly improved. The context for the second marked discussion board was the NIMBY problem, something that came up frequently in case studies presented in l ecture. Students were asked to discuss how, in the context of renewabl e energy, to balance the rights of $\mathrm{i}$ ndividuals against a potential societal benefit. A controversial proposed wind farm was provided as an exam ple. Fi nally, near the end of the course, the students were asked for $\mathrm{t}$ he third marked discussion board to discuss which renewable energy technologies have the greatest potential to contribute to Canada's energy needs. The second and third marked discussion boards had part icipation from 95 (70\%) and $110(81 \%)$ st udents respectively. Marks on these two were nearly identical, 8.6 out of 10 .

In the end, 5 st udents didn't participate in any of the discussion boards and another 7 responded $t$ o only one discussion board. We are t rying to follow up and understand why these students essentially threw away marks - was $t$ his through misunderstanding or is there some impediment to their participation, e.g. poor language skills or simply shyness? It is clear that we need to do more next year to achieve full class participation in the discussion boards.

\subsection{Problem Assignments}

The problem assignments were designed to give the students practice using the concepts learned in class and also to encourage them to explore the behavior of various renewable energy systems, e.g. by performing a sensitivity analysis and plotting their results. Some problems were made up in response to student questions. 
For example, questions from students showed that they were having difficulty understanding the tradeoffs between fluid outlet temperature and flow rate in a solar collector. Assignm ent \#4 therefore asked them to explore this tradeoff with a sim ple numerical model. Problem assignments were post ed on the course Blackboard and students ubmitted their com pleted assignments online. Marked assignm ents were also returned online.

\section{SIMULATION AND ECONOMIC ANALYSIS}

Economic rather than technical issues are $\mathrm{t}$ he weakness of most renewable energy technologies. In order to provide the students with a real istic understanding, each student wa s asked to analyze the performance of a proposed wi nd turbine installation for an off-grid power sy stem on an island off the coast of Newfoundland. The si mulation is not numerically challenging - at the level of an Excel spreadsheet, but students have to choose from multiple procedures and data forms to carry o ut the simulation. Using the projected electricity output for the system, the students had to estimate the cost of power production and conduct a sensitivity analysis to establish which parameters have the largest influence on costs. The simulation and economic analysis was $10 \%$ of the final course mark.

\section{EXAMINATIONS}

A midterm examination and a final examination (30\% and $40 \%$ of $t$ he final mark respectively) at which the students were $\mathrm{p}$ hysically present constituted the largest portion of the student's course mark, consistent with normal course practice and faculty regulations. The midterm exam was held in the early evening for the convenience of part-time graduate students.

\section{CHALLENGES ENCOUNTERED IN FALL 2011}

A number of technical diffi culties were encountered that challenged the students and tested the patience of the course teaching assistants.with such a word).

\subsection{Lecture Capture}

On the whole, the lecture capture worked very well. However, some lessons in reliability were learn ed very quickly. The vi deo camera used had its own recording capability, which provided a backup to the Echo 360 Capture hardware. Despi te having two parallel systems, the voice recording component failed after only a week of classes. This necessitated re-recording two lectures in an alternative format and introduced a nearly one week delay in posting lectures. The students were remarkably patient as long as they were kept informed of the progress. For the remainder of the term, an independent voice recorder was used to provide at hird backup for $t$ he voice component.

\subsection{Assignment submission}

Students were required to submit problem sets online. There was no com mon technology for doing so and this resulted in huge fi les - e.g. camera images of homework pages - being submitted. Th is presented challenges for Blackboard and for $\mathrm{t}$ he subsequent marking process. For Fall 2012, arrangements have been made for scanners to be placed in the library for use by on-campus students. Most individuals don't have access to a scan ner, so use of cameras will be still part of the process for at least off-campus students. An Information Engineering colleague has poi nted us to a num ber of smart phone aps that create a compact pdf file from a cell phone camera images. These are bei ng evaluated with a view to specifying their use when a camera is used in lieu of a scanner. Thi s would support specifying that all assignments be submitted in pdf format, which would resolve the issues around submission.

\subsection{Assignment Marking}

Submitted assignments were d ownloaded to a tablet PC for paperless marking. The assi gnments could be downloaded as a bat ch from Blackboard, although the large file sizes made this process more time consuming than it needed to be. Marked assignm ents were uploaded to Blackboard for vi ewing by students. Unfortunately there is no provision for batch uploading to Blackboard so this was a tedious procedure, complicated by inconsistent file names. For Fall 2012, a required file naming convention will be im plemented for all assignments to minimize time spent uploading.

\subsection{Interaction}

Part of the difficulty is a t echnology problem in facilitating this type of communication. $\mathrm{W}$ e are investigating hardware and so ftware that might make it easier for st udents to quickly submit hand calculations and sketches that might move discussion along. We plan to incorporate the most convenient technology we can find into the Fall 2012 course structure. 


\section{PLANNED IMPROVEMENTS}

The following changes are $\mathrm{pl}$ anned for Fall 2012 to address issues identified from the Fall 2011 experience:

1. An introductory online tutorial covering online learning technology. Students employ all sorts of devices and software, but there is a need for technology that interacts well with our Course Learning Management Software (currently Blackboard) to minimize frustration and time spent accessing the system.

2. The lectures will co ntinue to be delivered in asynchronous mode since some graduate students taking the course are part-time students with full-time jobs. They need the flexibility of choosing a time to watch the lectures. Howeve $r$, the course instructor will offer a live online question session, likely in the evening for easy access by the part-tim e students. This will allow students to ask lecture questions that they would have asked in a live lecture. It will also allow students to ask questions about the problem sets. In both cases, the live online session provides a second option to asking questions on a di scussion board.

\section{CHALLENGES FOR FALL 2012}

Comments received from the small group of students who attended the video capture lectures were particularly interesting because they had both options open to them Their views were mixed. Contrast:

"online lectures very helpful and very convenient ... making whole course online better idea,"

and

"I enjoyed the lectures and felt th at the online component worked quite well. Earlier in the term I was able to attend only $1 / 2$ of $t$ he lectures per week but there was no detrim ental effect to $\mathrm{m} y$ learning due to the online lecture videos,"

with
"I like the dynamics of the in-class environm ent. A little disappointed to hear that the class will be $100 \%$ online in the future,"

$$
\text { and }
$$

"I am happy that I could follow the course in class because one learns so $\mathrm{m}$ uch more than when watching just a video. I prefer havi ng an in-class course much to an online course."

The students like the freedom to choose the viewing time, as well as th e ability to review lectures multiple times. The challenge for Fall 2012, is to provide them a timely and simple means of asking spontaneous questions and then sharing the questions and responses with the entire class. Our focus for Fall 2012 will be on developing a sch eduled online session to facilitate this process.

\section{Acknowledgements}

The authors gratefully acknowledge Provost Cheryl Misak and Vi ce-Provost - Academ ic Programs Cheryl Regehr for supporting the on line pilot course initiative and Dean Cristina Amon and Vice-Dean Susan McCahan for providing technical support resources. Regular meetings with Laurie Harrison, Director - Online Learning Strategies and the online pilot course team were a tremendous source of ideas and practices. Thanks are due to Teaching Assistants Pradyumna Challa, Terry Jung and Meghdad Saffaripour for being part of $t$ his experiment and for their patience and valuable feedback. Thanks also to Matthieu Gagné for vi deo-capture technical support and editing.

\section{References}

[1] Rena M. Palloff and Keith Pratt, Building Online Learning Communities, Effective Strategies for the Virtual

Classroom, $2^{\text {nd }}$ Edition, Jossey-Bass, San Francisco (2007).

[2] Godfrey Boyle, Editor, Renewable Energy: Power for a Sustainable Future, $2^{\text {nd }}$ Edition, Oxford University Press, Oxford (2004). 